\title{
Mathematical modeling of the sorption isotherms of three varieties of industrial cassava
}

\section{Modelamiento Matemático de las isotermas de sorción de tres variedades de yuca industrial}

\author{
Angélica María Torregroza-Espinosa ${ }^{l}$, Jhonatan Andrés Rodríguez-Manrique ${ }^{l}$, Rolando José López-Martínez ${ }^{l}$ \\ and Ana Carolina Torregroza-Espinosa ${ }^{2}$ \\ ${ }^{I}$ Corporación Universitaria del Caribe-CECAR, Facultad de Ciencias Básicas Ingeniería y Arquitectura, Sincelejo, Colombia, \\ angelica.torregroza@cecar.edu.co \\ ${ }^{2}$ Corporación Universidad de la Costa-CUC, Facultad de Ingeniería, Programa de Ingeniería Agroindustrial, Barranquilla, Colombia.
}

Received: September 6th, 2012. Received in revised form: November 1th, 2013. Accepted: November 25th, 2013.

\begin{abstract}
A completely randomized design was used to model the sorption isotherms of three types of industrial cassava. The samples consisted of slices $(3.6 \mathrm{~cm} \times 0.6 \mathrm{~cm} \times 0.5 \mathrm{~cm})$ of three varieties of cassava: Corpoica Tai, Corpoica Gynes and Corpoica Veronica. Temperature was set at $20{ }^{\circ} \mathrm{C}, 30^{\circ} \mathrm{C}$ and $45^{\circ} \mathrm{C}$. All experiments were performed in triplicate. Data were obtained through an experimental dynamic method to calculate desorption and adsorption isotherms. Results were analyzed for each temperature, and isotherms were calculated for each variety. Isotherms were statistically equal for all temperatures at a $95 \%$ confidence level. The isotherms were adjusted based on mathematical models (GAB, BET, Smith, Oswin, Henderson, and Peleg). The GAB model was considered the most appropriate for data correlation.
\end{abstract}

Keywords: equilibrium moisture content; model adjustment; adsorption; desorption.

\section{Resumen}

Con el fin de modelar las isoterma de sorción de láminas $(3.6 \mathrm{~cm} \times 0.6 \mathrm{~cm} \times 0.5 \mathrm{~cm})$ de tres variedades de yuca industrial, se empleó un diseño completamente al azar en arreglo factorial con dos factores: temperatura $\left(20^{\circ} \mathrm{C}, 30{ }^{\circ} \mathrm{C}\right.$ y $\left.45^{\circ} \mathrm{C}\right)$ y variedad (Corpoica Tai, Corpoica Gynes y Corpoica Veronica), con tres repeticiones. Para la obtención de los datos se empleó la técnica experimental del método dinámico para determinar las isotermas de desorción y adsorción. Los datos obtenidos fueron analizados para cada temperatura, determinándose las isotermas para las variedades estudiadas, las cuales fueron estadísticamente iguales entre sí para las tres temperaturas utilizadas aun nivel de confianza del 95\%. Las isotermas fueron ajustadas a los modelos matemáticos de Gab, Bet, Smith, Oswin, Henderson y el modelo de Peleg y se determinó que el modelo de GAB es el más adecuado para correlacionar los datos obtenidos.

Palabras clave: humedad de equilibrio; ajuste del modelo; adsorción; desorción.

\section{Introduction}

Cassava or yucca (Manihot esculenta Crantz) belongs the spurge family (Euphorbiaceae). Around 98 species of the genus Manihot have been described, however, only yucca is considered economically important and is grown in many parts. Also known as mandioca, this perennial plant is native to South America [1] and is quite common in tropical areas of about 90 countries in America, Asia and Africa.

Together with corn, sugarcane and rice, cassava is one of the most important source of energy in the tropics. Roots are the edible part of this plant although the foliage is used as animal feed, and as vegetables for human consumption in Africa [2].
According to the 2015 National Agricultural Survey, ENA, by its Spanish acronym [3], Colombia produced 518,482 tons of cassava in 2014, with average yields of 12.4 tons per hectare per year. The department of Meta is the main producer with 175.104 tons (33.6\% of the total production) followed by the departments of Magdalena, Sucre, Bolivar, and among others.

In Colombia, cassava is mainly grown by small-scale farmers, with an average of planted areas ranging from one to five hectares per farm. Much of cassava production is oriented towards the fresh produce market. However, the Colombian government through its National Development Plan "Towards a Community State" developed a strategy

Digital Object Identifier (DOI):

http://dx.doi.org/10.18687/LACCEI2019.1.1.154

ISBN: 978-0-9993443-6-1 ISSN: 2414-6390

$1^{\text {th }}$ LACCEI International Multi-Conference for Engineering, Education, and Technology: “Industry, Innovation, And Infrastructure for Sustainable Cities and Communities", 24-26 July 2019, Jamaica. 
aimed at strengthening the existing production chains and boost cassava production. Today, as a result of this governmental program, cassava production continues to increase substantially, as well as yields, in an effort to substitute the import of raw materials for the feed industry and the poultry industry [4].

Cassava is aimed mainly at four markets depending on its use: as a root for human consumption, as raw material for the food industry, as an intermediate product, and as raw material for the animal feed industry, where its use has increased significantly [4]. Drying and dehydration processes provide foods with lighter consis tency as well as improved taste, smell and resistance, in addition to facilitate transport [5]. Drying-dehydration processes are also a useful tool for the development of new products for the agro-industrial sector [6].

Isotherms are defined as the relationship between the moisture content of foods and air temperature and relative humidity, which makes it essential for preservation of dehydrated foods. The equilibrium relative humidity of foods and the air relative humidity play an important role in processes related to drying, conservation and conditioning of food raw materials, in addition to being a useful tool to help structure storage and rehydration systems, and determining food stability [7].

Therefore, proper understanding of the rehydration kinetics is necessary for optimal storage conditions and reduce product loss.

\section{Materials and Methods}

\section{A. Sample preparation}

Raw materials consisted of samples of industrial cassava of the varieties Corpoica Tai, Corpoica Veronica and Corpoica Gynes, which were supplied by ASPROALGA, a local association of agricultural producers based on the department of Córdoba, Colombia. The samples were conditioned based on the shape and size typically used in drying processes.

The samples were cut into slices $(3.6 \mathrm{~cm}$ long $\mathrm{x} 0.6 \mathrm{~cm}$ wide $\mathrm{x} 0.5 \mathrm{~cm}$ thick) using a lab scale cutting machine in order to allow better contact with the surrounding drying air.

\section{B. Preparing sorption isotherms and mathematical modeling of data}

Collection of experimental data needed to calculate the equilibrium curves for cassava samples was performed as follows.

The LabMaster-aw neo water activity meter with salt standards and $0-0.95$ activity range was used in this experiment. Each sample was placed in the sample analyzer together with the certified salts until the equilibrium was reached. This procedure was repeated for each of the salts.

Equilibrium curves were calculated using the method described by Rossi and Roa [8], which consists of plotting the equilibrium relative humidity on a dry basis vs the relative humidity of the air. The results obtained were adjusted to mathematical models (GAB, BET, Henderson, Peleg, Caurie, Smith, Oswin, Halsey and Iglesias- Chirife) as shown in Table I.

Table I.

Mathematical models to be adjusted in the equilibrium humidity data for each cassava variety.

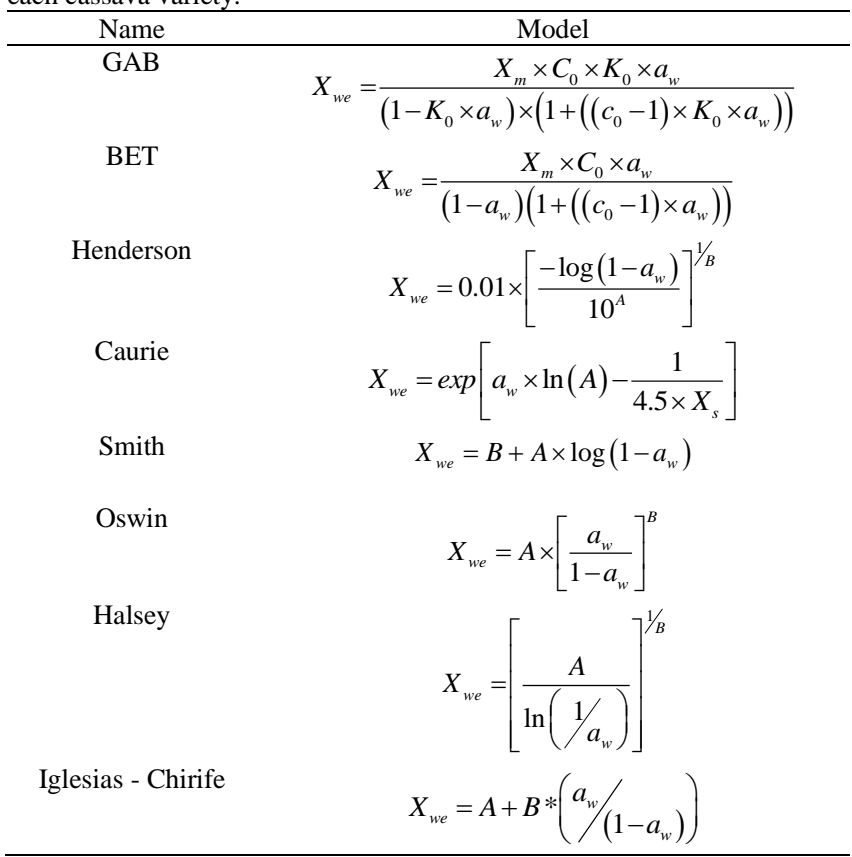

Source: [7]

\section{Data processing and statistical analysis}

Data processing was performed through an analysis of variance in order to compare temperature and variety, and determine whether interaction occurs between these two factors.

Also, Tukey's range test (5\% significance-level) was performed along with model assumption tests (normality, independence and homogeneity of variance). The evaluation of the adjustment quality resulting from the models proposed was performed based on factors such as linear regression coefficient $\left(\mathrm{R}^{2}\right)$, sum of squared errors (SSE), and residual plot. The lowest SSE values (close to zero) as well as the highest values for $\mathrm{R}^{2}$ (close to 1 ) were considered the most appropriate to choose the appropriate mathematical model [9]. The analysis was carried out using R Studio 1.0.44 software.

$1^{\text {th }}$ LACCEI International Multi-Conference for Engineering, Education, and Technology: "Industry, Innovation, And 


\section{Results and discussion}

The hygroscopic equilibrium of cassava samples was calculated by desorption and adsorption at temperatures of 20 ${ }^{\circ} \mathrm{C}, 30^{\circ} \mathrm{C}$ and $45^{\circ} \mathrm{C}$ as shown in Table II.

Table II

Hygroscopic equilibrium moisture content per $\mathrm{Kg}$ water/ $\mathrm{Kg}$ dry solid in samples of three cassava varieties at temperatures of $20^{\circ} \mathrm{C}, 30^{\circ} \mathrm{C}$ and $45^{\circ} \mathrm{C}$.

\begin{tabular}{|c|c|c|c|c|c|c|}
\hline \multirow[t]{2}{*}{${ }^{\circ} \mathrm{C}$} & \multicolumn{2}{|c|}{ Corpoica Tai } & \multicolumn{2}{|c|}{ Corpoica Gynes } & \multicolumn{2}{|c|}{ Corpoica Veronica } \\
\hline & $\overline{A_{w}}$ & $\mathrm{X}_{\mathrm{bs}}$ & $\overline{A_{w}}$ & $\mathrm{X}_{\mathrm{bs}}$ & $\mathrm{A}_{\mathrm{w}}$ & $\mathrm{X}_{\mathrm{bs}}$ \\
\hline \multirow{9}{*}{20} & 0.989 & 1.568 & 0.960 & 1.882 & 0.989 & 3.545 \\
\hline & 0.967 & 1.414 & 0.958 & 1.720 & 0.965 & 3.270 \\
\hline & 0.954 & 1.192 & 0.881 & 1.394 & 0.889 & 2.988 \\
\hline & 0.439 & 0.173 & 0.456 & 0.157 & 0.475 & 0.310 \\
\hline & 0.152 & 0.125 & 0.156 & 0.103 & 0.159 & 0.243 \\
\hline & 0.415 & 0.151 & 0.440 & 0.137 & 0.459 & 0.290 \\
\hline & 0.700 & 0.203 & 0.717 & 0.221 & 0.706 & 0.381 \\
\hline & 0.811 & 0.279 & 0.839 & 0.362 & 0.803 & 0.516 \\
\hline & 0.884 & 0.303 & 0.891 & 0.432 & 0.865 & 0.674 \\
\hline \multirow{9}{*}{30} & 0.965 & 1.599 & 0.962 & 1.880 & 0.943 & 2.572 \\
\hline & 0.934 & 1.457 & 0.933 & 1.770 & 0.919 & 2.358 \\
\hline & 0.822 & 0.904 & 0.859 & 1.520 & 0.847 & 1.931 \\
\hline & 0.614 & 0.633 & 0.733 & 1.208 & 0.715 & 1.333 \\
\hline & 0.157 & 0.178 & 0.164 & 0.087 & 0.168 & 0.142 \\
\hline & 0.423 & 0.218 & 0.446 & 0.135 & 0.453 & 0.194 \\
\hline & 0.746 & 0.332 & 0.747 & 0.240 & 0.722 & 0.339 \\
\hline & 0.863 & 0.457 & 0.863 & 0.366 & 0.839 & 0.537 \\
\hline & 0.927 & 0.589 & 0.920 & 0.497 & 0.902 & 0.750 \\
\hline \multirow{9}{*}{45} & 0.989 & 1.637 & 0.980 & 1.944 & 0.961 & 4.085 \\
\hline & 0.922 & 1.359 & 0.914 & 1.664 & 0.900 & 3.524 \\
\hline & 0.823 & 0.674 & 0.819 & 1.018 & 0.803 & 2.345 \\
\hline & 0.570 & 0.239 & 0.624 & 0.379 & 0.617 & 1.228 \\
\hline & 0.163 & 0.061 & 0.212 & 0.156 & 0.203 & 0.332 \\
\hline & 0.451 & 0.101 & 0.490 & 0.118 & 0.489 & 0.414 \\
\hline & 0.749 & 0.196 & 0.742 & 0.200 & 0.725 & 0.519 \\
\hline & 0.872 & 0.324 & 0.862 & 0.331 & 0.847 & 0.674 \\
\hline & 0.949 & 0.513 & 0.932 & 0.495 & 0.916 & 1.048 \\
\hline
\end{tabular}

Source: The authors

The above figure shows that that the equilibrium moisture values expressed in $\mathrm{Kg}$ water/Kg dry solid (dry basis) are higher for cassava of the variety Corpoica Veronica, while Corpoica Tai and Corpoica Gynes cassava varieties have similar values. Results for equilibrium moisture in Corpoica Tai cassava at temperatures of $20{ }^{\circ} \mathrm{C}, 30^{\circ} \mathrm{C}$ and $45^{\circ} \mathrm{C}$ are close, as occurs in the other varieties. These results are shown in Table III along with the analysis of variance (ANOVA). The analysis suggests a highly significant influence (at a 95\% confidence level) of the variety variable on the equilibrium moisture content as well a significant influence of the varietytemperature interaction. The comparison of means test showed significant differences between cassava of the variety Corpoica Veronica and the other two varieties. Likewise, Corpoica Veronica cassava has the highest equilibrium moisture values.
Table III

Analysis of variance for equilibrium moisture in cassava of the varieties.

\begin{tabular}{lcccrr}
\hline Source & DF & Type III SS & Mean Square & F Value Pr $>$ F \\
\hline VARD & 2 & 0.23778135 & 0.11889068 & 20.71 & $<.0001$ \\
TEMP & 2 & 0.05034241 & 0.02517121 & 4.39 & 0.0172 \\
VARD*TEMP & 4 & 0.27029042 & 0.06757261 & 11.77 & $<.0001$ \\
\hline
\end{tabular}

Source: Data provided by the authors

In Table 4, the parameters adjusted for the different mathematical equilibrium models, evaluated by nonlinear regression, of the experimental data of hygroscopic equilibrium of the laminae of the three varieties of cassava obtained by desorption and Adsorption for temperatures of $20{ }^{\circ} \mathrm{C}, 30^{\circ} \mathrm{C}$ and $45^{\circ} \mathrm{C}$; With the respective linear regression coefficients $\left(\mathrm{R}^{2}\right)$ and the sum of the square errors (SSE).

Table IV indicates that the Gab and Caurie models better fit experimental data, while the remaining models, despite being used to describe hygroscopicity in various foods, showed the lowest adjustment to experimental data with respect to equilibrium moisture of industrial cassava, as shown by the regression coefficient values and the sum of squared errors.

Since the Gab model best fits experimental data, it can provide valuable information regarding the moisture content in the monomolecular layer $\left(X_{m}\right)$, which is a fundamental parameter for storage conditions due to its high stability. On the other hand, $X_{m}$ value indicates the presence of active sites suitable for water absorption [10].

The values of the parameters of the GAB model allow to interpret the adsorption behavior. When $C>1$ and $k<<1$ it indicates the presence of structured molecules in both the monolayer and the multilayer, and their behavior differs from that of the molecules of the liquid fraction. If $k \approx 1$, the water molecules attached to the monolayer are not structured in a multilayer, and behave similarly to the molecules of the liquid fraction. When $C \approx 1$ there are no differences between the molecules of the monolayer and those of the multilayer. On the other hand, the larger the value of $C$, the greater the binding strength of the water in the monolayer (strongly bound water) and so the difference in enthalpy between the molecules of both the monolayer and the multilayer [10].

Similar studies with vegetables such as green onion, leeks, and green pepper, as well as dehydrated aromatic plants [11] and grains such as rice, corn and wheat [12] suggest that the GAB model provides a good description of experimental data to calculate equilibrium moisture content. In recent years the $\mathrm{GAB}$ model has been widely used to describe sorption isotherms of a variety of foods [13-15]; as well as ther studies on foods from plants and animals [16-21]. 
Table IV.

Parámetros de las ecuaciones ajustadas de las tres variedades de yuca estudiadas, para las diferentes temperaturas.

\begin{tabular}{|c|c|c|c|c|c|c|c|c|c|c|}
\hline \multicolumn{5}{|c|}{ Corpoica Tai } & \multicolumn{3}{|c|}{ Corpoica Gynes } & \multicolumn{3}{|c|}{ Corpoica Veronica } \\
\hline \multicolumn{2}{|c|}{ Model } & $20^{\circ} \mathrm{C}$ & $30^{\circ} \mathrm{C}$ & $45^{\circ} \mathrm{C}$ & $20^{\circ} \mathrm{C}$ & $30^{\circ} \mathrm{C}$ & $45^{\circ} \mathrm{C}$ & $20^{\circ} \mathrm{C}$ & $30^{\circ} \mathrm{C}$ & $45^{\circ} \mathrm{C}$ \\
\hline \multirow{5}{*}{$\mathrm{Gab}$} & $\mathrm{X}_{\mathrm{m}}$ & 6,043 & 0,402 & 21,617 & 63,302 & 101,601 & 34,166 & 136,796 & 2,073 & 8,797 \\
\hline & $\mathrm{C}_{\mathrm{o}}$ & 0,059 & 2,261 & 0,012 & 0,012 & 0,026 & 0,013 & 0,012 & 0,621 & 0,156 \\
\hline & $\mathrm{K}_{\mathrm{o}}$ & 0,636 & 0,809 & 0,689 & 0,548 & 0,340 & 0,641 & 0,519 & 0,642 & 0,625 \\
\hline & $\mathrm{R}^{2}$ & 0,980 & 0,916 & 0,945 & 0,899 & 0,955 & 0,910 & 0,945 & 0,981 & 0,786 \\
\hline & SSE & 0,121 & 0,418 & 0,303 & 0,948 & 0,297 & 0,703 & 1,814 & 0,224 & 7,938 \\
\hline \multirow{4}{*}{ Bet } & $\mathrm{X}_{\mathrm{m}}$ & 0,010 & 0,070 & 0,018 & 0,047 & 0,092 & ------ & 0,022 & 0,177 & 0,196 \\
\hline & $\mathrm{C}_{\mathrm{o}}$ & 131031,055 & 626407,480 & 213525,429 & 342501,291 & 638256,064 & ------ & 191343,722 & 1257657,075 & 848109,160 \\
\hline & $\mathrm{R}^{2}$ & ------ & 0,436 & 0,029 & 0,092 & 0,044 & ----- & ------ & 0,616 & 0,351 \\
\hline & SSE & 7,589 & 2,813 & 5,679 & 8,531 & 6,304 & ------ & 50,981 & 4,468 & 24,062 \\
\hline \multirow{4}{*}{ Herderson } & $\mathrm{A}$ & ------ & ------ & ------ & ------ & ------ & ------ & ------ & ------ & ------ \\
\hline & B & ------ & ------ & ------ & ------ & ------ & ------ & ----- & ----- & ----- \\
\hline & $\mathrm{R}^{2}$ & ------ & ------ & ------ & ------ & ------ & ------ & ------ & ------ & ------ \\
\hline & SSE & ------ & ------ & ------ & ----- & ------ & ------ & ------ & ----- & ----- \\
\hline \multirow{4}{*}{ Caurie } & $\mathrm{A}$ & 43,592 & 25,534 & 110,036 & 34,018 & 12,868 & 59,044 & 27,649 & 21,785 & 33,377 \\
\hline & $\mathrm{X}_{\mathrm{S}}$ & 0,067 & 0,084 & 0,054 & 0,079 & 0,124 & 0,067 & 0,112 & 0,113 & 0,114 \\
\hline & $\mathrm{R}^{2}$ & 0,981 & 0,919 & 0,948 & 0,901 & 0,937 & 0,913 & 0,946 & 0,978 & 0,787 \\
\hline & SSE & 0,112 & 0,403 & 0,407 & 0,933 & 0,413 & 0,678 & 1,792 & 0,261 & 7,902 \\
\hline \multirow{4}{*}{ Smith } & $\mathrm{A}$ & $-0,714$ & $-1,093$ & $-0,888$ & $-1,205$ & $-1,318$ & $-1,217$ & $-1,683$ & $-2,093$ & $-3,041$ \\
\hline & B & 0,106 & 0,101 & 0,034 & 0,049 & 0,211 & 0,049 & 0,404 & 0,086 & 0,093 \\
\hline & $\mathrm{R}^{2}$ & 0,906 & 0,906 & 0,882 & 0,820 & 0,872 & 0,863 & 0,784 & 0,968 & 0,774 \\
\hline & SSE & 0,556 & 0,470 & 0,691 & 1,690 & 0,846 & 1,070 & 7,177 & 0,377 & 8,386 \\
\hline \multirow{4}{*}{ Oswin } & $\mathrm{A}$ & 0,467 & 0,503 & 0,440 & 0,585 & 0,758 & 0,562 & 1,265 & 0,857 & 1,227 \\
\hline & $\mathrm{B}$ & 0,250 & 0,370 & 0,304 & 0,325 & 0,309 & 0,338 & 0,225 & 0,411 & 0,400 \\
\hline & $\mathrm{R}^{2}$ & 0,825 & 0,880 & 0,807 & 0,744 & 0,844 & 0,803 & 0,706 & 0,942 & 0,744 \\
\hline & SSE & 1,038 & 0,597 & 1,132 & 2,409 & 1,029 & 1,538 & 9,782 & 0,679 & 9,491 \\
\hline \multirow{4}{*}{ Halsey } & A & ------ & 0,036 & ------ & ------ & 0,036 & ------ & ------ & 0,494 & ------ \\
\hline & B & ------ & 0,044 & ------ & ------ & 0,044 & ----- & ----- & 2,111 & ------ \\
\hline & $\mathrm{R}^{2}$ & ------ & ------ & ------ & ------ & ------ & ------ & ------ & 0,912 & ------ \\
\hline & SSE & ------ & 13,309 & ------ & ------ & 26,643 & ------ & ------ & 1,025 & ------ \\
\hline \multirow{4}{*}{$\begin{array}{c}\text { Iglesias } \\
- \\
\text { Chirife }\end{array}$} & $\mathrm{A}$ & 0,627 & 0,487 & 0,526 & 0,634 & ------ & 0,653 & 1,595 & 0,729 & 1,229 \\
\hline & B & 0,005 & 0,048 & 0,012 & 0,029 & ------ & 0,028 & 0,012 & 0,130 & 0,135 \\
\hline & $\mathrm{R}^{2}$ & 0,367 & 0,710 & 0,520 & 0,427 & ------ & 0,555 & 0,293 & 0,776 & 0,594 \\
\hline & SSE & 3,761 & 1,450 & 2,813 & 5,384 & ------ & 3,475 & 23,496 & 2,602 & 15,066 \\
\hline
\end{tabular}

Figures 1-9 show experimental data adjustment as well as the experimental data related to equilibrium moisture based on water activity in the desorption-adsorption process of three types of cassava.

The behavior of equilibrium curves (desorption and adsorption) for all cassava varieties and for the three temperatures, resembles a type II isotherm. According to Barbosa-Cánovas et al. [22], type II isotherms are the most common in foods, and its sigmoidal shape is attributed to capillary effects and aqueous interactions on the surface.
This isotherm can be divided into three regions. In the first area, water is strongly bound to polar groups of polysaccharides in the food and has an enthalpy of vaporization considerably greater than that of pure water. This region is responsible for the moisture of the monolayer and has a water activity of around 0.2 to 0.3 , therefore the rate of quality loss is negligible. In region $\mathrm{B}$, water molecules are less bound than in the previous area and the energy of evaporation is slightly higher than that required to evaporate 
pure water, while the properties of the solvent in the region $\mathrm{C}$ are very similar to those of pure water [23].

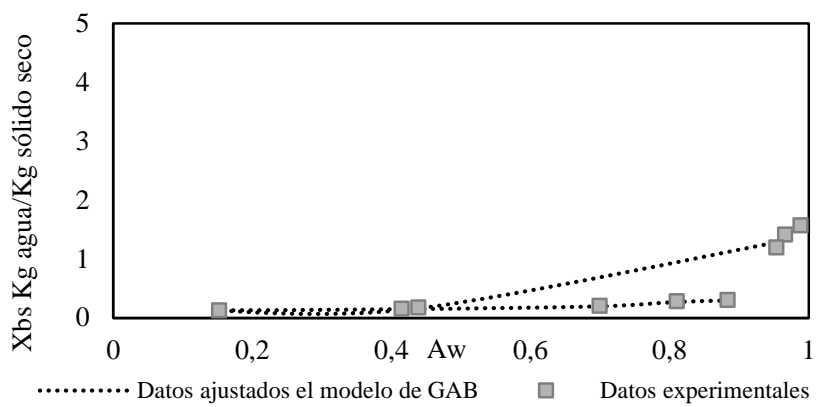

Figure 1. Sorption curves for Corpoica Tai cassava. $20^{\circ} \mathrm{C}$. Source: Data provided by the authors.

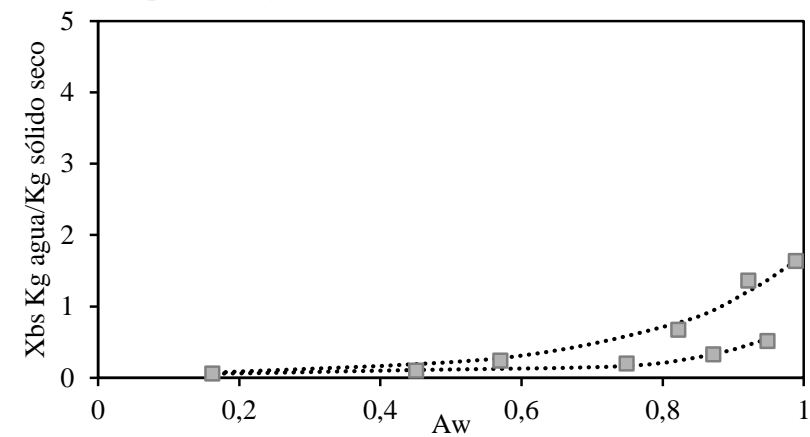

Figure 3. Sorption curves for Corpoica Tai cassava. $45^{\circ} \mathrm{C}$. Source: Data provided by the authors.

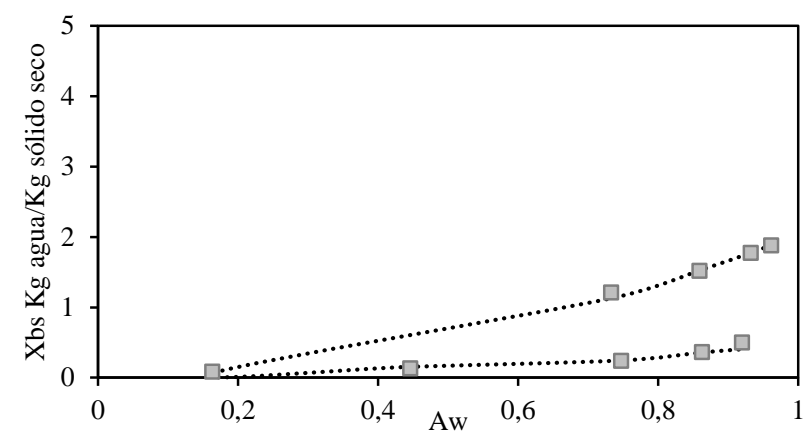

Figure 5. Sorption curves for Corpoica Gynes cassava. $30^{\circ} \mathrm{C}$. Source: Data provided by the authors.

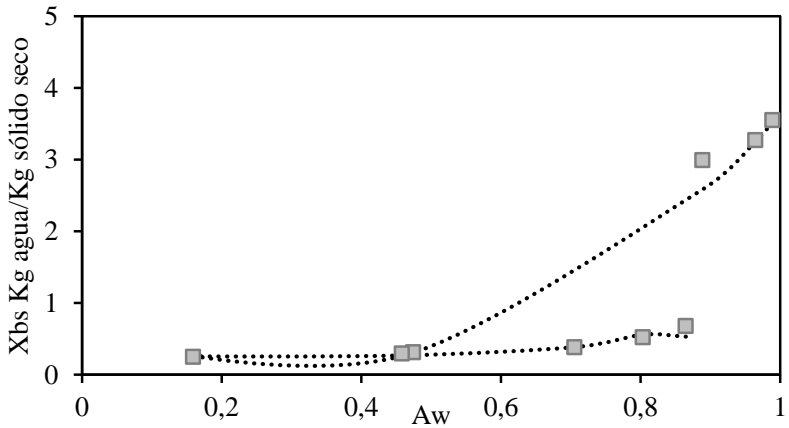

Figure 7. Sorption curves for Corpoica Veronica cassava. $20^{\circ} \mathrm{C}$. Source: Data provided by the authors.

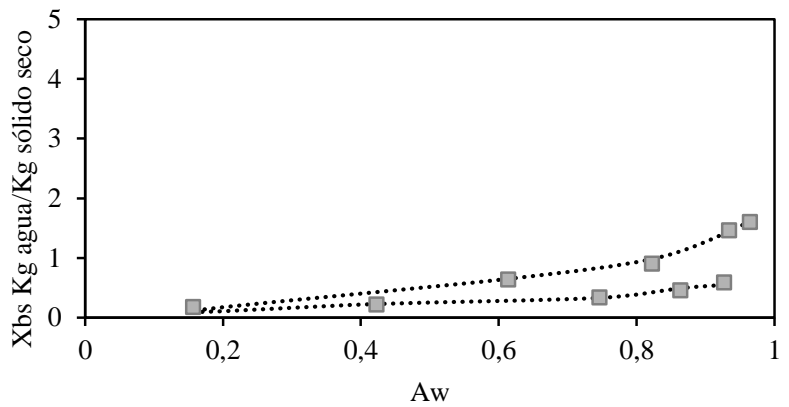

Figure 2. Sorption curves for Corpoica Tai cassava. $30^{\circ} \mathrm{C}$. Source: Data provided by the authors.

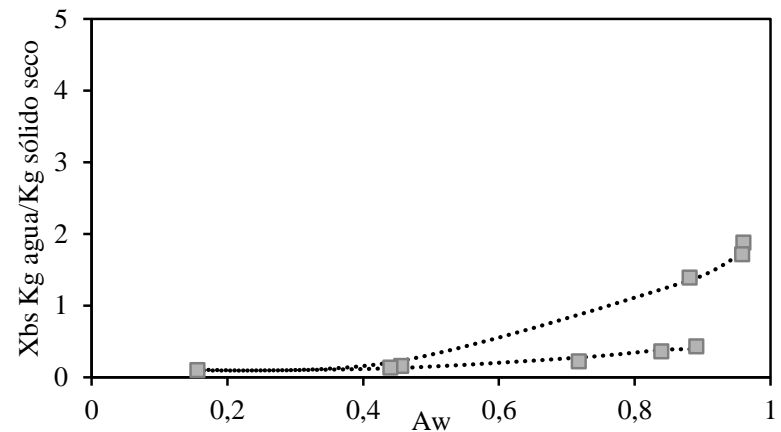

Figure 4. Sorption curves for Corpoica Gynes cassava. $20^{\circ} \mathrm{C}$. Source: Data provided by the authors.

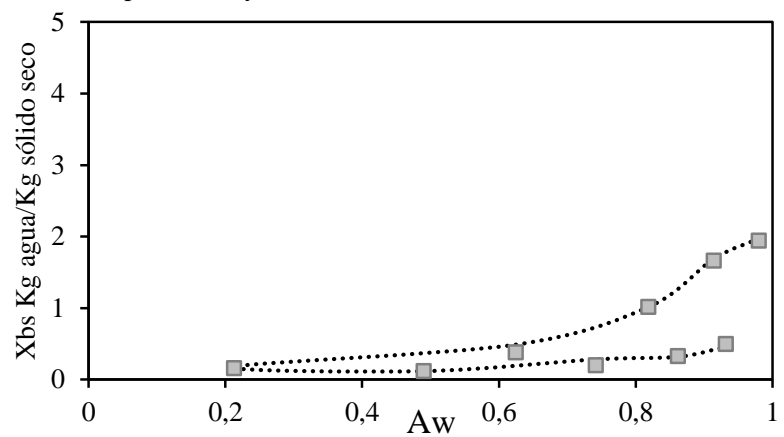

Figure 6. Sorption curves for Corpoica Gynes cassava. $45^{\circ} \mathrm{C}$. Source: Data provided by the authors.

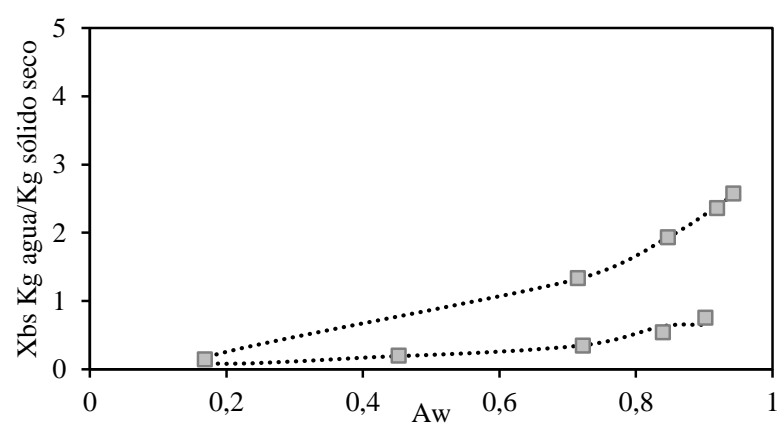

Figure 8. Sorption curves for Corpoica Veronica cassava. $30^{\circ} \mathrm{C}$. Source: Data provided by the authors.

$17^{\text {th }}$ LACCEI International Multi-Conference for Engineering, Education, and Technology: “Industry, Innovation, And 


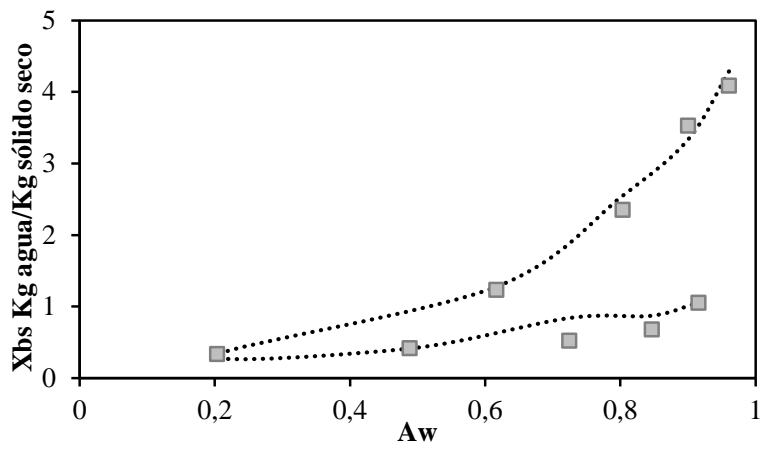

Figure 9. Sorption curves for Corpoica Veronica cassava. $45^{\circ} \mathrm{C}$. Source: Data provided by the authors.

Similar behaviors (Type II) were reported for samples of cassava flour by authors [24-26]; tomato pulp [27]; potato slices [28]; bananas [29]; corn starch [30]; and cassava starch [31].

\section{Conclusions}

The equilibrium moisture content for cassava of the varieties Corpoica Tai, Corpoica Gynes and Corpoica Veronica showed statistically significant differences at a level of significance of $5 \%$ while the equilibrium moisture content for temperatures of $45^{\circ} \mathrm{C}, 55^{\circ} \mathrm{C}$, and $70^{\circ} \mathrm{C}$ had no statistically significant differences.

The behavior of desorption-adsorption isotherms for the three varieties of cassava is properly described by the $\mathrm{GAB}$ and Caurie models. However, the GAB model best fits the behavior of the experimental equilibrium data.

The behavior of the equilibrium curves (desorptionadsorption) for the three varieties of cassava and for all temperatures, resembles a type II isotherm, which is the most common in foods. The sigmoidal shape of type II isotherms is attributed to capillary effects and aqueous interactions on the surface.

\section{References}

[1] Olsen, K.M. and Schaal, B.A. Microsatellite variation in cassava (Manihot esculenta, Euphorbiaceae) and its wild relatives: further evidence for a southern Amazonian origin of domestication. Am. J. Bot. 88, 131-142, 2001.

[2] Ceballos, H. and De la Cruz, A. Taxonomía y morfología de la yuca. En: Ceballos, H. y Ospina, B. La yuca en el tercer milenio. Sistemas modernos de producción, procesamiento, utilización y comercialización, p. 28. CIAT. Cali, Colombia. 586 pp, 2002.

[3] Agronet. Sistemas de estadísticas Agropecuarias- SEA, Estadísticas Agroforestales MADR_DANE_GREMIOS_1987-2013 - Consolidado Nacional (2015)

[4] Martínez, A. "seminario la yuca como componente de la cadena avícola", Julio 2003

[5] García, M., Alvis A. and García C.. Evaluación de los pretratamientos de deshidratación osmótica y microondas en la obtención de hojuelas de mango (Tommy Atkins). Inf. Tecnol. 26(5), 63-70, 2015.

[6] Martínez, E., Torregroza A., Torregroza A. and Mogollón D. Efecto de la deshidratación osmótica-microondas sobre propiedades fisicoquímicas del mango (Mangifera indica L.) variedad Corazón. Agronomía Colombiana 34: 1236-1239, 2016.
[7] Montes, E., Torres, R., Andrade, R., Pérez, O., Marimon, J. y Meza, I., Modelado de las isotermas de desorción del ñame (Dioscorea rotundata), DYNA, 76 (157), pp. 145-152, 2009.

[8] Rossi, J. R., Roa, G. Secagem e armazanamento de produtos agropecuários com uso de energia solar e ar natural. Sao Pablo: ACIESP, 293p, 1980.

[9] Akpinar, E., Bicer, Y. and Yildiz, C., Thin layer drying of red pepper. Journal of Food Engineering, 59 (1), pp. 99-104, 2003.

[10] Quirijns, E., Boxtel, A., Loon, W., and Straten, G. Sorption isotherms, $\mathrm{GAB}$ parameters and isosteric heat of sorption. Journal of the Science of Food and Agriculture, 85, 1805-1814, 2005.

[11] García, S., Schmalko, M., and Tanzariello, A. Isotermas de adsorción y cinética de secado de ciertas hortalizas y aromáticas cultivadas en misiones. RIA, 36 (1): 115-129, 2007.

[12] Prieto, J., Prieto, F., Román A., Otazo, E., and Méndez. M.; Correlación de modelos matemáticos de adsorción de humedad en cereales para desayuno. Avances en Ciencias e Ingeniería, VOL. 3(1), pp. 137-150. 2012.

[13] [Maroulis, Z.B., Tsami, E. and Marinos, D. Application of the GAB model to the moisture sorption isotherms for dried fruits. Journal of Food Engineering 7, pp63-78, 1988.

[14] Hyun K., Yoonseok S. and Yam K. L. Water sorption characteristic of dried red peppers (Capsicum annum L.) International Journal of Food Science and technology 29, pp339-345, 1991.

[15] Maroulis, Z.B., Kiranoudis, C.T., and Marinos Kouris, D. Heat and mass transfer modeling in air drying of foods. Journal of Food Engineering, vol26, 113-130, 1995.

[16] Iglesias, H.A. and Chirife, J. An alternative to de Guggenheim, Anderson and De Boer model for the mathematical description of moisture sorption isotherms of foods. Food Research inernational. Vol.28, N³, pp317-321, 1995.

[17] Diosady, L.L. Rizvi, S.S.H. Cai, W. and Jadgeo, D.J. Moisture sorption isotherms of canola meals, and applications to packaging. Journal of Food Science vol61, N¹ pp204-208, 1996.

[18] Timmermann, E.O., Chirife, J. and Iglesias, H.A. Water sorption isotherms of foods and foodstuffs: BET or GAB parameters, Journal of Food Engineering 48, 19-31, 2001.

[19] Giovanelli,G., Zanoni, B., Lavelli, V., and Nani, R. Water sorption, drying and antioxidant properties of dried tomato products. Journal of Food Engineering. Vol. 52, 135-141, 2002.

[20] Viswanathan, R., Jayas, D.S., and Hulasare, R.B. Sorption isotherms of tomato slices and onion shreds. Biosystems Engineering 86 (4), 465472, 2003.

[21] Krokida, M.K., Karathanos. V.T., Maroulis, Z.B. and Marinos-Kouris. D. Drying kinetics of some vegetables. J. Food Eng., 59, 391-403, 2003.

[22] Barbosa-Cánovas, G.V., Fontana, A.J., Schmidt, S.J. and Labuza, T.P. Water Activity in Foods: Fundaments and Applications, Blackwell publishing Ltd, 2007.

[23] Badui, S., Valdés Martínez, S. E., and Cejudo, H. Química de los alimentos (4a ed.). México [etc.]: Pearson Educación. 2006.

[24] Alvarado, L. Obtención de la harina de yuca para el desarrollo de productos dulces destinados para la alimentación de celiacos. Tesis de Grado. Escuela politécnica superior del litoral. Facultad de ingeniería mecánica y producción. Guayaquil-Ecuador, 2009.

[25] Ayala, A. Estimación de las isotermas de absorción y del calor isostérico en harina de yuca. Biotecnología en el Sector Agropecuario y Agroindustrial 20(1):88-96, 2011.

[26] Navia, D., Ayala, A., and Villada, H., Isotermas de adsorción de bioplásticos de harina de yuca moldeados por compresión, Biotecnología en el Sector Agropecuario y Agroindustrial: 9(1), 77-87, 2011.

[27] Goula M., Adamopoulos G. and Kazakis A. Influence of Spray Drying Conditions on Tomato Powder Properties, Drying Technology, 22:5, 1129-1151, 2007.

[28] Iguedjtal , T., Louka , N., and Allaf , K. Sorption isotherms of Granny Smith apples hot-air dried and texturized by "controlled sudden decompression to the vacuum." International Journal of Food Engineering, 3(5), 2007.

[29] Zhengyong, M., Sousa, J., and Oliveira A., Effect of temperature and initial moisture content on sorption isotherms of banana dried by tunnel 
drier International Journal of Food Science \& Technology 43(8):1430 $-1436,2008$.

[30] Peng, G., and Westerfield, M. Lhx5 promotes forebrain development and activates transcription of secreted Wnt antagonists. Development (Cambridge, England). 133(16):3191-3200, 2006.

[31] Perdomo, J., Cova, A., Sandoval, A., García, L., Laredo, E., and Müller, A. Glass transition temperatures and water sorption isotherms of cassava starch. Carbohydrate Polymers, v.76, n.2, p.305-313, 2009.

$17^{\text {th }}$ LACCEI International Multi-Conference for Engineering, Education, and Technology: “Industry, Innovation, And Infrastructure for Sustainable Cities and Communities”, 24-26 July 2019, Jamaica. 